\title{
First descriptions of dicyemid mesozoans (Dicyemida: Dicyemidae) from Australian octopus (Octopodidae) and cuttlefish (Sepiidae), including a new record of Dicyemennea in Australian waters
}

\author{
Sarah R. Catalano $0^{1,2,3,4}$ \\ ${ }^{1}$ Marine Parasitology Laboratory, The University of Adelaide, North Terrace, Adelaide, South Australia, Australia; \\ ${ }^{2}$ Southern Seas Ecology Laboratories, The University of Adelaide, North Terrace, Adelaide, South Australia, Australia; \\ ${ }^{3}$ Evolutionary Biology Unit, The South Australian Museum, North Terrace, Adelaide, South Australia, Australia; \\ ${ }^{4}$ Australian Centre for Evolutionary Biology and Biodiversity, The University of Adelaide, North Terrace, Adelaide, South \\ Australia, Australia
}

\begin{abstract}
Three new species of dicyemid mesozoans are described for the first time from Australian octopus and cuttlefish species. Dicyemennea floscephalum sp. $\mathrm{n}$. is described from Octopus berrima Stranks et Norman (southern keeled octopus) collected from Spencer Gulf and Gulf St. Vincent, South Australia, Australia and represents the first description of a species of Dicyemennea Whitman, 1883 from Australian waters. Dicyema papuceum sp. n. and D. furuyi sp. n. are described from Sepia papuensis Hoyle (Papuan cuttlefish) collected from Shark Bay, Western Australia, Australia. Dicyemennea floscephalum sp. n. is a medium to large species that reaches approximately $4.9 \mathrm{~mm}$ in length. The vermiform stages are characterised by having 23-28 peripheral cells, and a discshaped, flower-like calotte in larger individuals. An anterior abortive axial cell is absent in vermiform embryos and verruciform cells were not observed in nematogens and rhombogens. Infusoriform embryos comprise 37 cells; one nucleus is present in each urn cell. Dicyema papuceum sp. $\mathrm{n}$. is a small species that reaches approximately $1.1 \mathrm{~mm}$ in length. The vermiform stages are characterised by having 30-33 peripheral cells and a relatively small, cap-shaped calotte. An anterior abortive axial cell is absent in vermiform embryos and verruciform cells were occasionally observed in nematogens. Infusoriform embryos comprise 37 cells; two nuclei are present in each urn cell. Dicyema furuyi $\mathrm{sp}$. $\mathrm{n}$. is a large species that reaches approximately $5.3 \mathrm{~mm}$ in length. The vermiform stages are characterised by having 22-24 peripheral cells and an elongate calotte. An anterior abortive axial cell is absent in vermiform embryos and verruciform cells were not observed in nematogens and rhombogens. Infusoriform embryos comprise 37 cells; one nucleus is present in each urn cell. Three secondary nematogens were also observed in the right renal appendages of two host individuals, confirming the occurrence of this form.
\end{abstract}

Keywords: Dicyema, taxonomy, morphology, renal appendages, Octopus berrima, Sepia papuensis, Spencer Gulf, Gulf St. Vincent, Shark Bay

The renal appendages (synonymous with kidneys, renal sacs and renal organs) of benthic cephalopods provide a unique, yet ideal, nutrient-rich habitat for the establishment and maintenance of a group of microscopic, wormlike organisms known as dicyemid mesozoan parasites (Hochberg 1982, Furuya and Tsuneki 2003, Furuya et al. 2004). These organisms, comprising only eight to 40 cells with neither body cavities nor differentiated organs, are highly host species specific, although more than one species can occur in each cephalopod individual or species, and occupy the renal appendages in densities of thousands of animals per $\mathrm{cm}^{3}$ (Furuya 1999, Furuya et al. 2007, Suzuki et al. 2010). The life cycle of dicyemid mesozoans is complex, with two modes of reproduction and two stages of development, and it is uncertain whether their affinities are with the Protozoa or Metazoa, hence the intermediate 'Mesozoa' classification (McConnaughey 1951, Furuya et al. 2001, 2003a, Catalano 2012).

Dicyemids have been documented and described previously from the western and north-eastern Pacific Ocean, northern Indian Ocean, Mediterranean Sea, north-western and eastern Atlantic Ocean, Gulf of Mexico and Antarctic Ocean (Furuya 2006). Published work on dicyemids from the southern hemisphere is scarce, with only two studies documenting dicyemid parasites from Australian waters. The first, by Finn et al. (2005), recorded the presence or absence of dicyemid species in 38 cephalopod species collected throughout southern, eastern and western Australia. However, of the 24 cephalopod species found to be infected, no formal descriptions of new dicyemid species 
Table 1. Dicyemid species from Octopus berrima and Sepia papuensis from Australian waters.

\begin{tabular}{|c|c|c|c|c|}
\hline \multicolumn{5}{|c|}{ Octopus berrima (southern keeled octopus) } \\
\hline \multicolumn{2}{|c|}{$\begin{array}{l}\text { No. of } \quad \text { ML } \\
\text { individuals }(\mathrm{cm}) \\
\text { examined }\end{array}$} & \multirow{2}{*}{$\begin{array}{l}\text { Locality } \\
\text { GSV, SA }\end{array}$} & \multirow{2}{*}{$\begin{array}{l}\begin{array}{l}\text { Examination } \\
\text { date }\end{array} \\
11 / 2010-03 / 2011\end{array}$} & \multirow{2}{*}{$\begin{array}{l}\text { Dicyemid } \\
\text { Dicyemennea } \\
\text { floscephalum sp. } \mathrm{n} .\end{array}$} \\
\hline 9 & $3.7-9$ & & & \\
\hline 13 & $3.5-7$ & SG, SA & $11 / 2010-10 / 2011$ & D. floscephalum sp. n. \\
\hline \multicolumn{5}{|c|}{ Sepia papuensis (Papuan cuttlefish) } \\
\hline $\begin{array}{l}\text { No. of } \\
\text { individuals } \\
\text { examined }\end{array}$ & $\begin{array}{l}\text { ML } \\
(\mathrm{cm})\end{array}$ & Locality & $\begin{array}{l}\text { Examination } \\
\text { date }\end{array}$ & Dicyemid \\
\hline 3 & $9.5-14$ & $\mathrm{SB}, \mathrm{WA}$ & June 2012 & $\begin{array}{l}\text { Dicyema papuceum } \\
\text { sp. } \mathrm{n} .\end{array}$ \\
\hline 4 & $12-17$ & SB, WA & June 2012 & $\begin{array}{l}\text { D. papuceum } \mathrm{sp} . \mathrm{n} \text {. } \\
\text { D. furuyi } \mathrm{sp} . \mathrm{n} \text {. }\end{array}$ \\
\hline
\end{tabular}

GSV - Gulf St Vincent; ML - Mantle Length range; SA - South Australia; SB - Shark Bay; SG - Spencer Gulf; WA - Western Australia.

were made. The second study, by Catalano and Furuya (2013), described two species of Dicyema von Kölliker, 1849 from two squid species collected from southern Australia, and represented the first descriptions of dicyemid parasites from Australian cephalopods.

Examination of dicyemid parasites from two Australian cephalopod species, i.e. southern keeled octopus, Octopus berrima Stranks et Norman (Octopodidae), and Papuan cuttlefish, Sepia papuensis Hoyle (Sepiidae), revealed three new dicyemid species. Here, I provide descriptions of these new dicyemid species including morphological comparisons to other similar described species and also comment on parasite prevalence, co-infection patterns and the role of secondary nematogens in the dicyemid life cycle. These findings subsequently represent the first record of a species of Dicyemennea Whitman, 1883 in Australia, first record of dicyemids from Australian octopus and cuttlefish species and confirmation of the occurrence of secondary nematogens.

\section{MATERIALS AND METHODS}

In this study, 22 individuals of Octopus berrima and seven individuals of Sepia papuensis collected between November 2010 and June 2012 were examined for dicyemids. Host specimens of $O$. berrima were obtained from the by-catch of prawn surveys (South Australian Research and Development Institute) in Spencer Gulf (SG) and Gulf St. Vincent (GSV), South Australia (SA), Australia and host specimens of S. papuensis were obtained from a research trawl in Shark Bay, off Carnarvon, Western Australia, Australia. All cephalopods were examined immediately upon capture. Host dorsal mantle length ranges $(\mathrm{cm})$, collection locality and date of examination were recorded for all cephalopod individuals and are presented in Table 1. Mantle length measurements for $O$. berrima individuals follows Norman and Sweeney (1997).

The method for dissecting each cephalopod individual is based on that used by Catalano and Furuya (2013). Briefly, the body of each cephalopod was placed ventral side up, the mantle cavity was opened to expose the paired renal sacs and small pieces of both the left and right renal appendages were removed and smeared onto glass microscope slides. Four smears were made per renal appendage, with a total of eight smears per host individual. All dissecting equipment was cleaned and sterilised in absolute ethanol to avoid cross contamination of preparations. The glass slide smears were fixed immediately and stored in $70 \%$ ethanol in the field, then stained and mounted upon returning to the laboratory. A mantle tissue sample was also taken for each host individual and preserved in 100\% DNA grade ethanol.

Smears were stained in Ehrlich's acid haematoxylin, dehydrated in an ethanol series, counterstained in eosin $1 \%$ alcoholic solution and mounted in Canada balsam following the method outlined in Catalano and Furuya (2013). Mounted smears were dried on a heated plate at $50^{\circ} \mathrm{C}$ before examination with a compound light microscope at magnifications up to $\times 1500$. Measurements and drawings were made with the aid of an ocular micrometre and a drawing tube. All measurements are in micrometres $(\mu \mathrm{m})$ and presented as mean and SD unless indicated otherwise.

The terminology for cell names used in the description of infusoriform larvae is based on Nouvel (1948), Short and Damian (1966) and Furuya (1999, 2009, 2010). Syntypes of the dicyemids are deposited in the Marine Invertebrate Collection (MIC), South Australian Museum, Adelaide (SAMA), South Australia, Australia (contact: Thierry Laperousaz, thierry.laperousaz@, samuseum.sa.gov.au), and the National Museum of Nature and Science, Tokyo (NSMT), Amakubo, Tsukuba City, Ibaraki, Japan (contact: Toshiaki Kuramochi, kuramoti@kahaku.go.jp). Tissue from the two cephalopod species harbouring dicyemid parasites are deposited in the Australian Biological Tissue Collection (ABTC) of the SAMA, South Australia, Australia (contact: Steve Donnellan, Steve.Donnellan@samuseum.sa.gov.au).

\section{RESULTS}

Family Dicyemidae van Beneden, 1882

Dicyemennea floscephalum sp. n. Figs. 1, 2; Tables 1, 2

Diagnosis: Medium- to large-sized dicyemid; body length reaching $4.9 \mathrm{~mm}$. Calotte disc-shaped, flower-like when viewed aerially in larger individuals. Vermiform stages with 23-28 peripheral cells: 4 propolars +5 metapolars +2 parapolars $+12-17$ trunk cells; 23 peripheral cells most common. Infusoriform embryos with 37 cells; refringent bodies solid; 1 nucleus present in each urn cell.

Nematogens (Figs. 1A,C, 2A,B,D; $n=42$ ): Body slender, length from 455 to $1.7 \mathrm{~mm}$, average length $982 \pm 261$, mode 900; width from 20-58, average width $33 \pm 9$, mode 30; trunk width mostly uniform (Figs. 1C, 2A,B). Peripheral cell number 23-27 (Table 2): 4 propolars +5 metapolars +2 parapolars $+10-14$ diapolars cells +2 uropolars. Calotte disc-shaped, flower-like, widest at metapolar cells (Figs. 1A, 2B,D). Cilia on calotte approximately 8 long, orientated anteriorly. Propolar cells and their nuclei smaller than metapolar cells and their nuclei, respectively (Figs. 1A, 2B,D). Cytoplasm of propolar and metapolar cells more darkly stained by haematoxylin and 

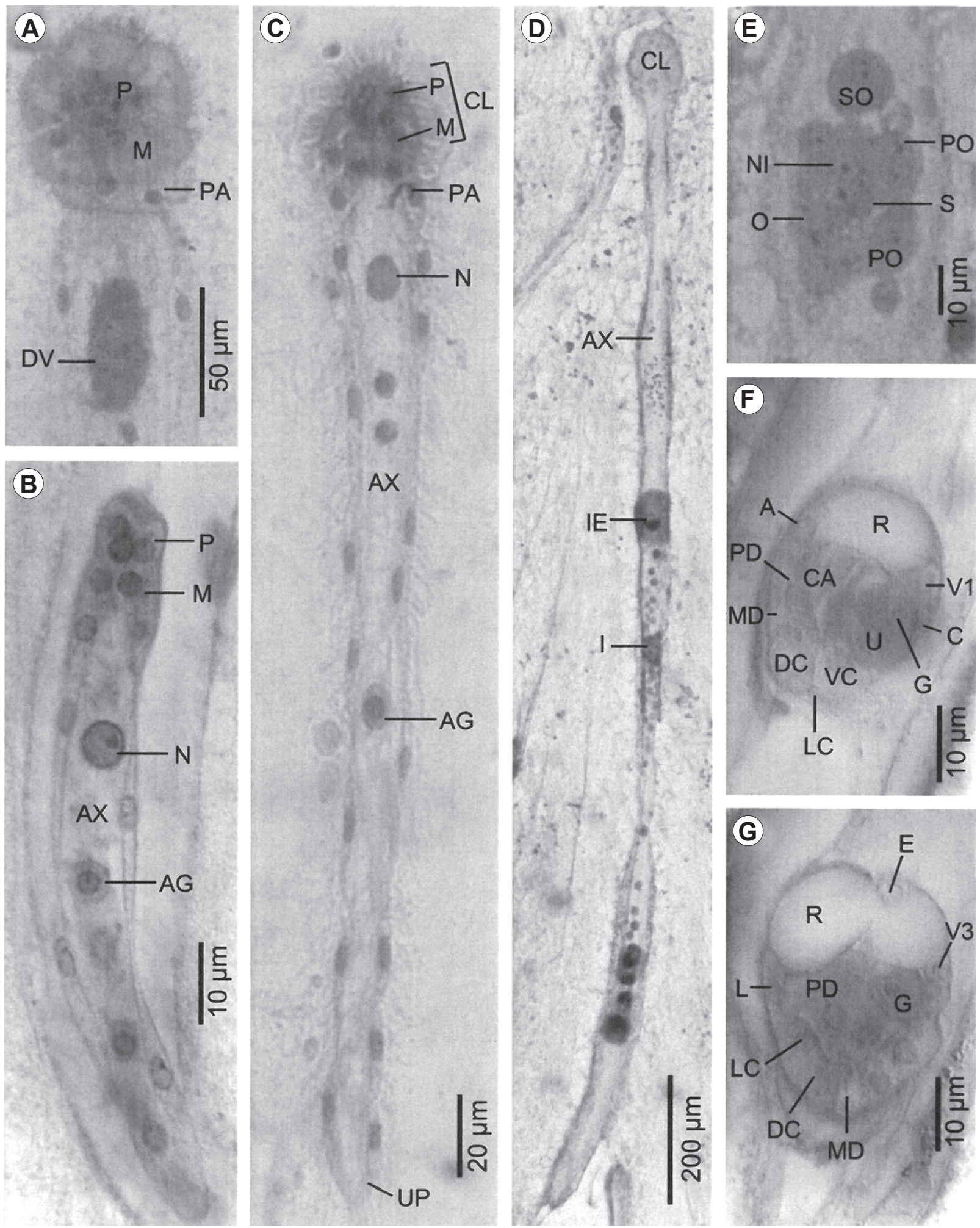

Fig. 1. Light micrographs of Dicyemennea floscephalum sp. n. from Octopus berrima Stranks et Norman. A - anterior region of nematogen; B - vermiform embryo within axial cell; $\mathbf{C}$ - young nematogen, entire; D - rhombogen, entire; $\mathbf{E}$ - infusorigen; F, $\mathbf{G}$ - infusoriform embryos within axial cell (F - optical sagittal section, $\mathrm{G}$ - optical horizontal section). Abbreviations: A - apical cell; AG - agamete; AX - axial cell; C - couvercle cell; CA - capsule cell; CL - calotte; DC - dorsal caudal cell; DV - developing vermiform embryo; E - enveloping cell; $\mathrm{G}$ - germinal cell; I - infusorigen; IE - infusoriform embryo; L - lateral cell; LC - lateral caudal cell; M - metapolar cell; MD - median dorsal cell; N - nucleus; NI - nucleus of infusorigen; O - oogonia; P - propolar cell; $\mathrm{PA}$ - parapolar cell; PD - paired dorsal cell; PO - primary oocytes; R - refringent body; S - spermatogonium; SO - secondary oocytes; U - urn cell; UP - uropolar cell; VC - ventral caudal cell; V1 - first ventral cell; V3 - third ventral cell. 
Table 2. Number of peripheral cells in Dicyemennea floscephalum sp. n., Dicyema papuceum sp. n. and Dicyema furuyi sp. n.

\begin{tabular}{|c|c|c|c|}
\hline & \multicolumn{3}{|c|}{ Dicyemennea floscephalum sp. n.: No. of individuals } \\
\hline Cell no. & Nematogens & Vermiform embryos & Rhombogens \\
\hline 23 & 24 & 31 & 17 \\
\hline 24 & 6 & 14 & 6 \\
\hline 25 & 5 & 14 & 1 \\
\hline 26 & 5 & 27 & 1 \\
\hline 27 & 3 & 14 & 0 \\
\hline 28 & 0 & 4 & 0 \\
\hline \multicolumn{4}{|c|}{ Dicyema papuceum sp. n.: No. of individuals } \\
\hline Cell no. & Nematogens & Vermiform embryos & Rhombogens \\
\hline 30 & 6 & 15 & 3 \\
\hline 31 & 3 & 4 & 1 \\
\hline 32 & 3 & 6 & 2 \\
\hline 33 & 0 & 6 & 0 \\
\hline \multicolumn{4}{|c|}{ Dicyema furuyi sp. n.: No. of individuals } \\
\hline Cell no. & Nematogens & Vermiform embryos & Rhombogens \\
\hline 22 & 11 & 6 & 3 \\
\hline 23 & 3 & 2 & 1 \\
\hline 24 & 1 & 1 & 2 \\
\hline
\end{tabular}

eosin than cytoplasm of other peripheral cells. Verruciform cells absent. Axial cell cylindrical, rounded anteriorly; extends forward to middle of propolar cells; posterior extent of axial cell through uropolar cells (Fig. 1C). Average of 6 vermiform embryos present in axial cell of nematogens, with larger individuals having as many as 27 vermiform embryos in axial cell. Agametes present and numerous in axial cell; average diameter $7.5 \pm 1.1$, mode 7.

Vermiform embryos (Figs. 1B, 2F-H; $\mathrm{n}=42$ ): Full-grown vermiform embryos 100-380 long, average length $164 \pm 68$, mode 100 ; width 8-26, average width $16 \pm 5$, mode 20 (Fig. 1B). Peripheral cell number 23-28 (Table 2): 4 propolars +5 metapolars +2 parapolars + 10-15 diapolars cells +2 uropolars; 23 peripheral cells most common (Fig. 2H). Anterior end of calotte rounded; propolar and metapolar cells of mostly equal width (Figs. 1B, 2G,H). Axial cell rounded anteriorly; extends forward to middle of propolar cells (Fig. 2G). Nucleus usually located anteriorly in axial cell (Figs. 1B, 2F,G). Anterior abortive axial cell absent. Axial cell of fullgrown embryos with as many as 3 agametes.

Rhombogens (Figs. 1D, 2C,E; $\mathrm{n}=42$ ): Body longer than nematogens, otherwise similar in width and shape; length from 890 to $4.9 \mathrm{~mm}$, average length $2.0 \mathrm{~mm} \pm 846$, mode $1.5 \mathrm{~mm}$, width 24-65, average width $37 \pm 9$, mode 30 (Figs. 1D, 2C). Peripheral cell number 23-26 (Table 2), 23 peripheral cells most common. Calotte discshaped, flower-like when viewed aerially (Fig. 2E). Axial cell shape and anterior extent similar to nematogen. Verruciform cells absent. Average of 13 infusoriform embryos present in axial cell of rhombogens, with smaller individuals having as few as 3 and larger individuals having as many as 48 . Usually 1 , rarely 2 infusorigens present in axial cell of each parent individual.
Infusorigens (Figs. 1E, 2I; $\mathrm{n}=40$ ): Mature infusorigens medium-sized; usually irregular in shape; diameters of 20-80, average of $34.2 \pm 11.5$. Composed of 7-42 (mode 18) external cells (egg line - oogonia and primary oocytes) $+5-21$ (mode 8 ) internal cells (sperm line - spermatogonia, primary spermatocytes and secondary spermatocytes) + 3-12 (mode 6) sperm (Figs. 1E, 2I). Mean diameter of fertilised eggs $11.4 \pm 2.4$, that of sperm $1.1 \pm 0.1$.

Infusoriform embryos (Figs. 1F,G, 2J-L; n = 200): Full-grown embryos medium-sized, lengths average $30 \pm 4$ (excluding cilia); length: width: depth ratio $1.00: 0.77: 0.87$. Shape ovoid, bluntly rounded (Figs. 1G, 2J,K). Cilia at posterior end 4.2 long. Refringent bodies present, solid and large; occupy $50 \%$ of embryo length when viewed laterally (Figs. 1F, 2L). Cilia projecting from ventral internal cells to urn cavity (Fig. 2L). Capsule cells contain many large granules (Fig. 2L). Mature infusoriform embryos consisting of 37 cells: 33 somatic +4 germinal cells. Somatic cells of several types present: external cells cover large part of anterior and lateral surfaces of embryo ( 2 enveloping cells); external cells with cilia on external surface ( 2 paired dorsal cells +1 median dorsal cell +2 dorsal caudal cells +2 lateral caudal cells +1 ventral caudal cell +2 lateral cells +2 posteroventral lateral cells); external cells with refringent bodies ( 2 apical cells); external cells without cilia (1 couvercle cell +2 first ventral cells +2 second ventral cells +2 third ventral cells); internal cells with cilia (2 ventral internal cells); and internal cells without cilia ( 2 dorsal internal cells +2 capsule cells +4 urn cells). Each urn cell contains 1 germinal cell and 1 nucleus. All somatic nuclei appear pycnotic in mature infusoriform embryos.

Type host: Southern keeled octopus - Octopus berrima Stranks et Norman (Mollusca: Cephalopoda: Octopodidae), $5 \mathrm{~cm}$ mantle length, $60 \mathrm{~g}$ weight (ABTC 125761).

Other hosts: None.

Type locality: Spencer Gulf(SG), South Australia, Aus-

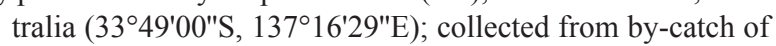
prawn survey.

Additional localities: Gulf St. Vincent (GSV), South Australia, Australia (344ㅇ' $\left.30^{\prime \prime} \mathrm{S}, 138^{\circ} 12^{\prime} 09^{\prime \prime} \mathrm{E}\right)$; collected from by-catch of prawn survey (ABTC 125762).

Site of infection: Attached to the surface of the left and right renal appendages.

Prevalence: 22 hosts infected/22 hosts examined $(100 \%$ infection rate); 13 hosts from SG, 9 hosts from GSV (Table 1).

Specimens deposited: Four syntype slides are deposited in the Marine Invertebrates Collection, SAMA, Australia (E3737-40) and three in the NSMT, Japan (NSMT-Me 23-25).

Etymology: The species name is derived from the Latin word flos, meaning 'flower', and the Greek word cephal, meaning 'head', in reference to the characteristic flowershaped calotte in adult stages when viewed from the top. 

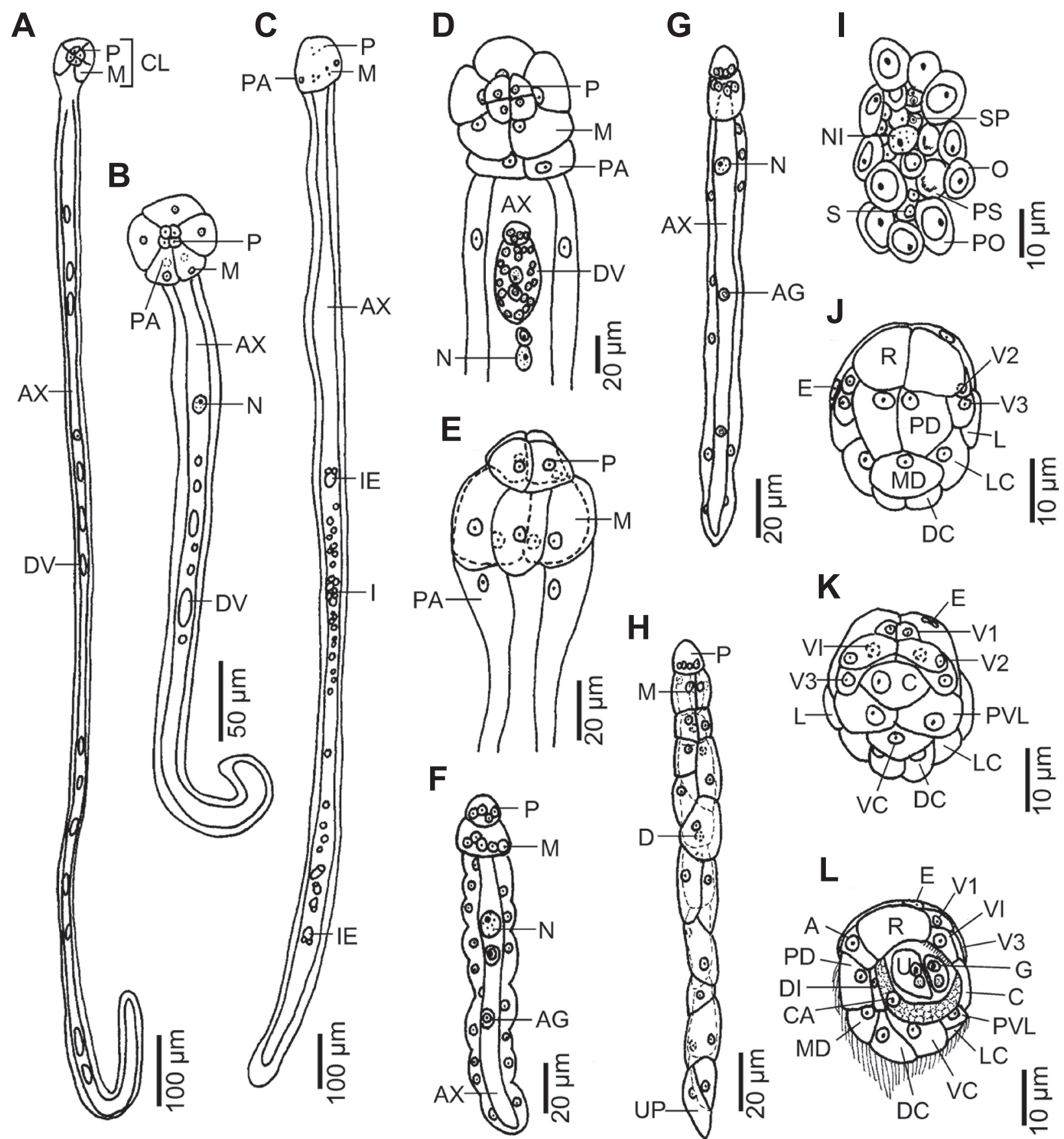

Fig. 2. Line drawings of Dicyemennea floscephalum sp. n. from Octopus berrima Stranks et Norman. A, B - nematogen, entire; $\mathbf{C}$ - rhombogen, entire; D - anterior region of nematogen; $\mathbf{E}$ - anterior region of rhombogen; $\mathbf{F}$ - vermiform embryo; $\mathbf{G}, \mathbf{H}$ - vermiform embryo within axial cell ( $\mathrm{G}$ - optical section, $\mathrm{H}$ - cilia omitted); $\mathbf{I}$ - infusorigen; $\mathbf{J}-\mathbf{L}$ - infusoriform embryos within axial cell ( $\mathrm{J}$ - dorsal view, cilia omitted, $\mathrm{K}$ - ventral view, cilia omitted, L - sagittal section). Abbreviations: D - diapolar cell; DI - dorsal internal cell; PS - primary spermatocytes; PVL - posteroventral lateral cells; SP - sperm; V2 - second ventral cell; VI - ventral internal cell. See Fig. 1 for other abbreviations.

Remarks. Of the 40 species of Dicyemennea currently described (see Catalano 2012), 30 partially overlap with a peripheral cell count range similar to that described for Dicyemennea floscephalum sp. n. (23-28). However, no species overlap with an identical peripheral cell count range, although $D$. abelis McConnaughey, 1949, with
23-29 peripheral cells and $D$. dorycephalum Furuya et Hochberg, 2002, with 23-27 peripheral cells, are most similar. Dicyemennea abelis was described from Octopus bimaculatus Verrill off the coast of California and can be distinguished from $D$. floscephalum based on smaller body sizes of adults, presence of an abortive second axial 


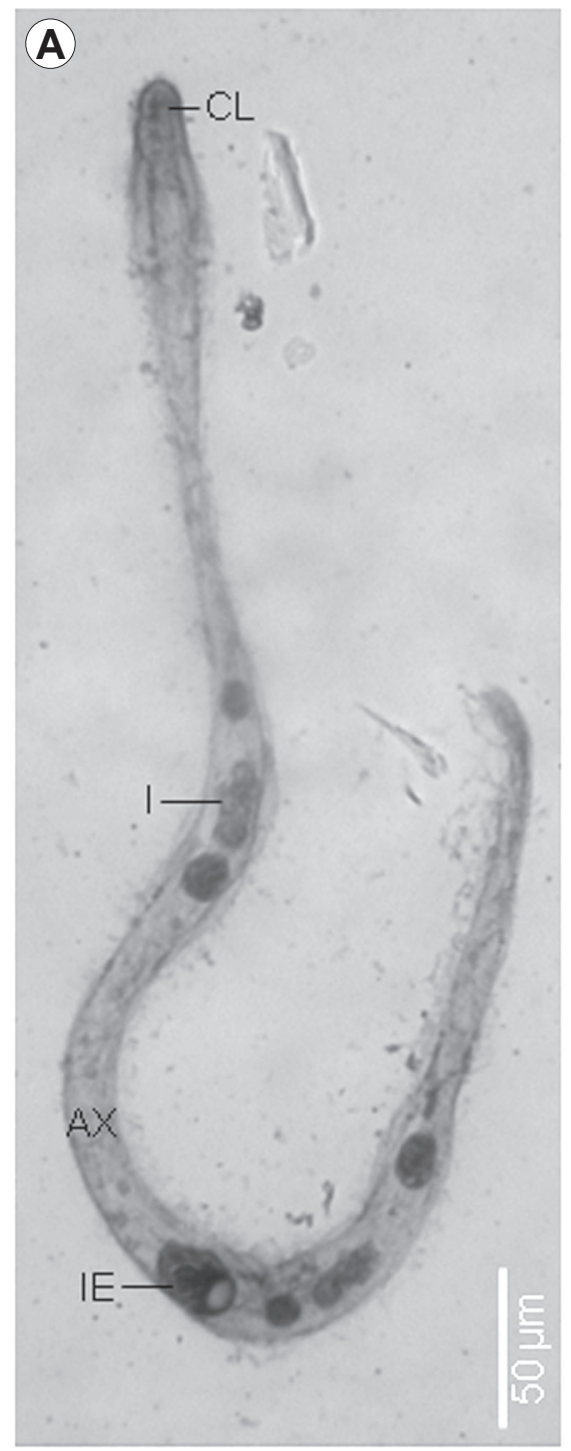

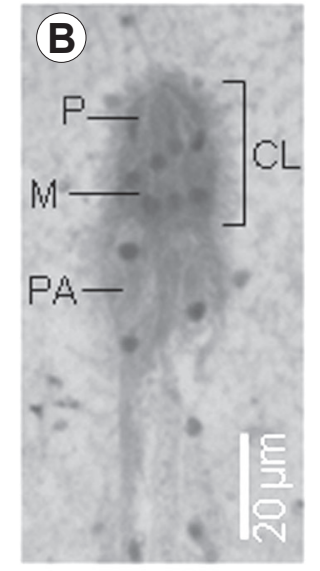

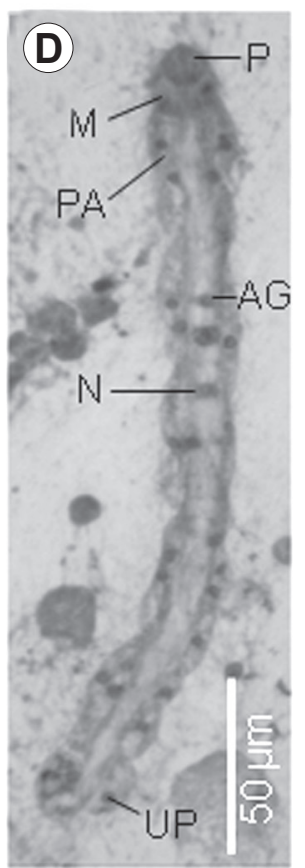

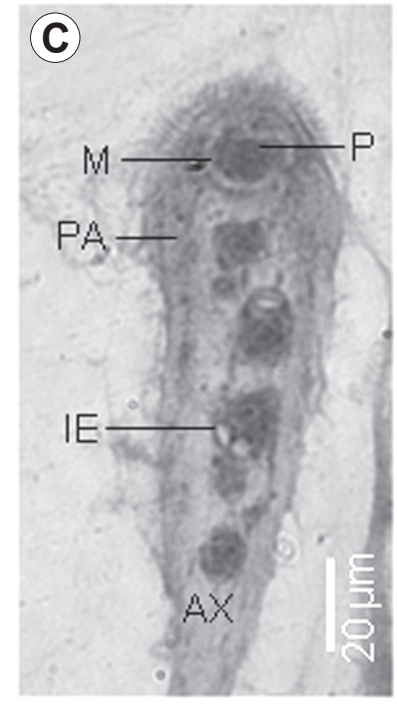
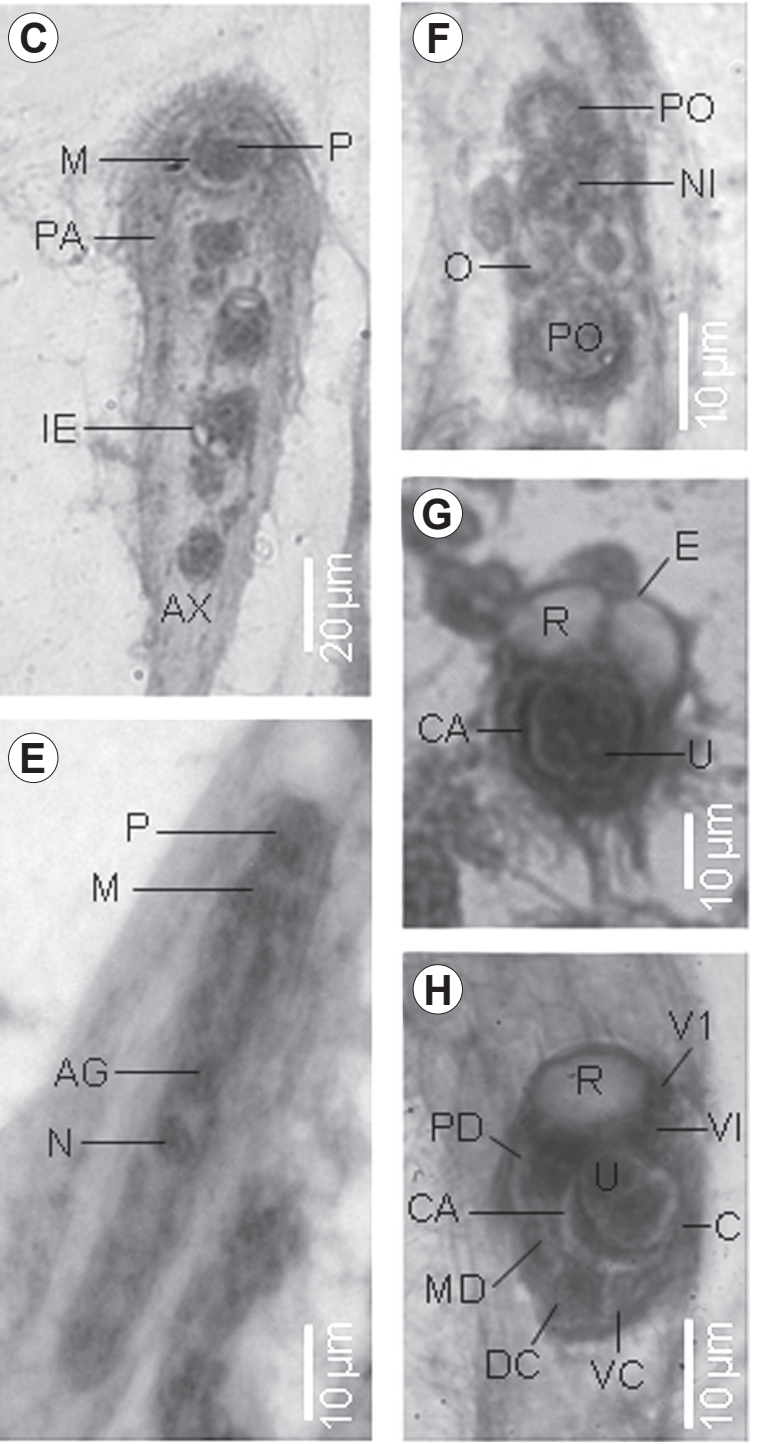

Fig. 3. Light micrographs of Dicyema papuceum sp. n. from Sepia papuensis Hoyle. A - rhombogen, entire; $\mathbf{B}$ - anterior region of nematogen; $\mathbf{C}$ - anterior region of rhombogen; D - young nematogen, entire; $\mathbf{E}$ - vermiform embryo within axial cell; $\mathbf{F}$ - infusorigen; $\mathbf{G}, \mathbf{H}$ - infusoriform embryos within axial cell ( $\mathrm{G}$ - optical horizontal section, $\mathrm{H}$ - optical sagittal section). Abbreviations: VI - ventral internal cell. See Fig. 1 for other abbreviations.

cell in vermiform larvae, presence of verruciform cells and larger infusoriform embryos with two nuclei in each urn cell (McConnaughey 1949a).

Dicyemennea dorycephalum was described from Graneledone macrotyla Voss, a deep water benthic cephalopod collected in the Southern Ocean south of the Antarctic Convergence (Furuya and Hochberg 2002). It differs from $D$. floscephalum most noticeably by having a distinctly pointed, spearhead-shaped calotte, although other characters, such as the presence of an anterior abortive axial cell in vermiform embryos, smaller body size of adults and smaller infusorigen axial cell diameter (Furuya and Hochberg 2002), can also be used to distinguish D. dorycephalum from $D$. floscephalum.

No other species share a similar body shape and size, calotte shape, cell number of infusoriform embryos and infusorigen composition to D. floscephalum. This is the first Dicyemennea described from Australian waters and also the first dicyemid to be described from an Australian Octopus.

Dicyema papuceum sp. $n$.

Figs. 3, 4; Tables 1, 2

Diagnosis: Small-sized dicyemid; body length reaching $1.1 \mathrm{~mm}$. Calotte relatively small, cap-shaped. Vermiform stages with $30-33$ peripheral cells: 4 propolars +4 metapolars +2 parapolars $+20-23$ trunk cells; 30 peripheral cells most common. Infusoriform embryos with 37 cells; refringent bodies solid; urn cell with 2 nuclei each.

Nematogens (Figs. 3B,D, 4A,C,E; $\mathrm{n}=21$ ): Body length from 288 to $1.1 \mathrm{~mm}$, average length $516 \pm 199$; 
A

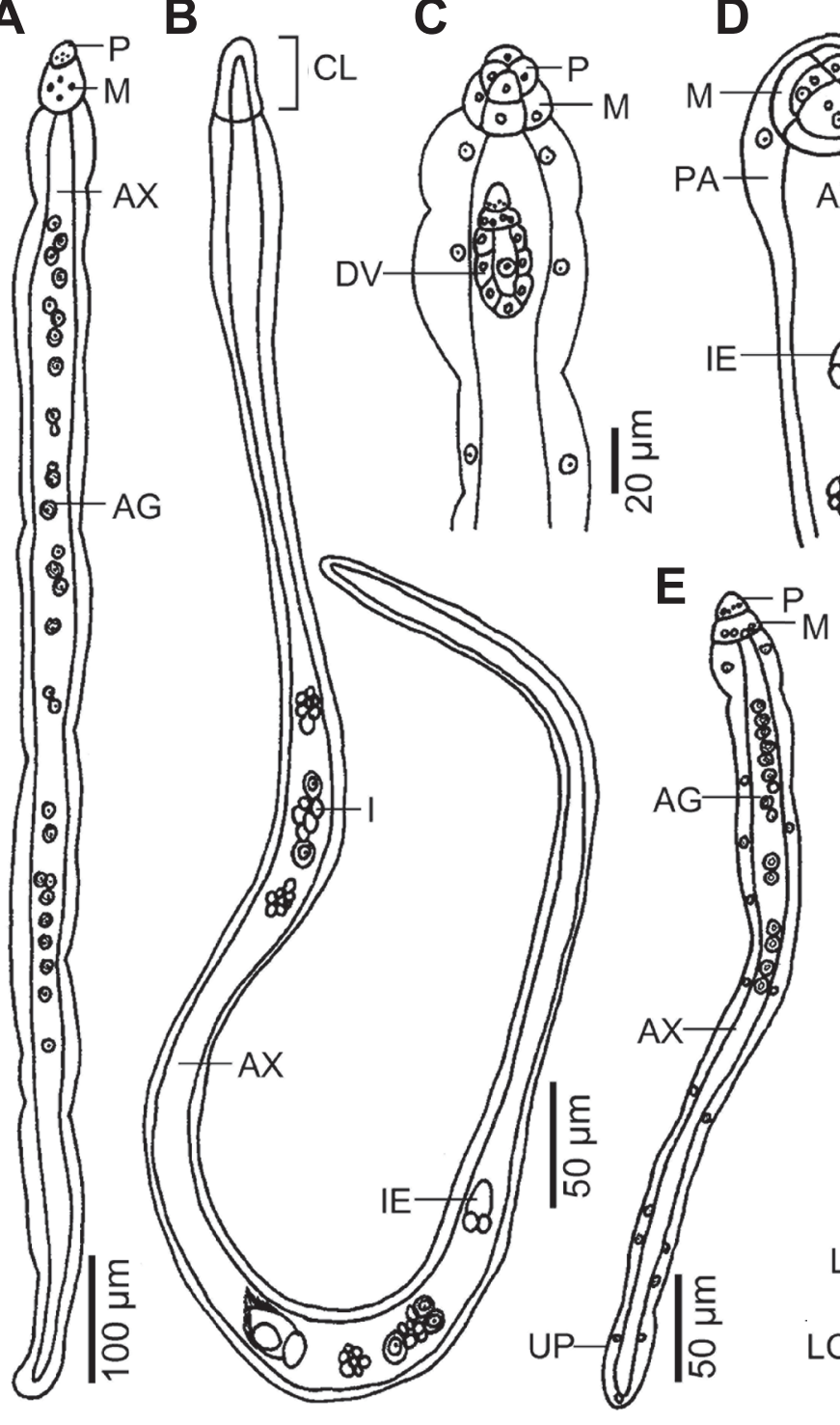

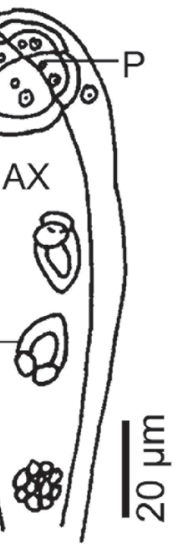
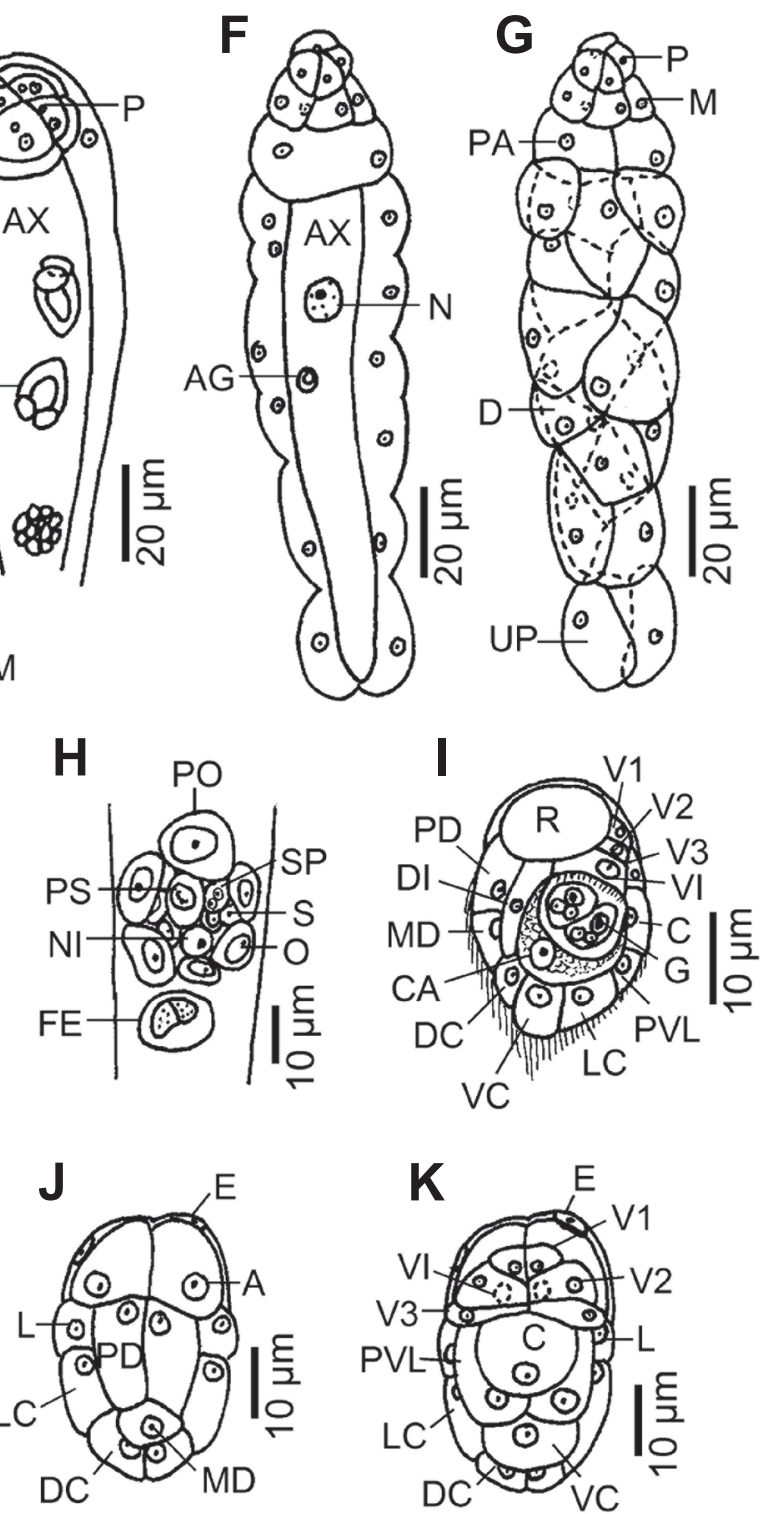

Fig. 4. Line drawings of Dicyema papuceum sp. n. from Sepia papuensis Hoyle. A - nematogen, entire; B - rhombogen, entire; $\mathbf{C}$ - anterior region of nematogen; $\mathbf{D}$ - anterior region of rhombogen; $\mathbf{E}$ - young nematogen, entire; $\mathbf{F}, \mathbf{G}$ - vermiform embryo within axial cell (F - optical section, $\mathrm{G}$ - cilia omitted); $\mathbf{H}$ - infusorigen; $\mathbf{I}-\mathbf{K}$ - infusoriform embryos within axial cell (I - sagittal section, $\mathrm{J}$ - dorsal view, cilia omitted, $\mathrm{K}$ - ventral view, cilia omitted). Abbreviations: D - diapolar cell; DI - dorsal internal cell; FE - fertilised egg; PS - primary spermatocytes; PVL - posteroventral lateral cells; SP - sperm; V2 - second ventral cell; VI - ventral internal cell. See Fig. 1 for other abbreviations.

width 10-48, average width $25 \pm 11$, mode 24; trunk width mostly uniform (Fig. 4A). Peripheral cell number 30-32 (Table 2): 4 propolars +4 metapolars +2 parapolars +18 to 20 diapolars cells +2 uropolars. Calotte small, cap-shaped, occasionally forming a cephalic swelling together with the parapolar cells (Figs. 3B,D, 4C,E). Cilia on calotte approximately 4.4 long, oriented anteriorly. Propolar cells and their nuclei smaller than metapolar cells and their nuclei, respectively (Figs. 3D, 4C,E). Cytoplasm of propolar and metapolar cells more darkly stained by haematoxylin and eosin than cytoplasm of other peripheral cells. Verruciform cells present, rare. Ax- ial cell cylindrical, rounded anteriorly; extends forward through metapolar cells to propolar cells; posterior extent of axial cell through uropolar cells (Fig. 4E). Average of 3 vermiform embryos present in axial cell of nematogens, with larger individuals having as many as 11 vermiform embryos in axial cell. Agametes present and numerous in axial cell; average diameter $5.6 \pm 0.8$, mode 6 .

Vermiform embryos (Figs. 3E, 4F,G; $n=21$ ): Fullgrown vermiform embryos 64-244 long, average length $169 \pm 54$, mode 160 ; width $12-30$, average width $18 \pm 5$, mode 16. Peripheral cell number 30-33 (Table 2): 4 propolars +4 metapolars +2 parapolars $+18-21$ diapolars cells 
+2 uropolars; 30 peripheral cells most common. Anterior end of calotte rounded; metapolar cells larger than propolar cells (Figs. 3E, 4G). Axial cell rounded anteriorly; extends forward to middle of propolar cells. Nucleus usually located in the centre of axial cell (Fig. 4F). Anterior abortive axial cell absent. Axial cell of full-grown embryos with as many as 11 agametes.

Rhombogens (Figs. 3A,C, 4B,D; $n=21$ ): Slightly shorter than nematogens, width and shape otherwise similar; length 240-712, average length $425 \pm 118$, mode 368 , width 28-56, average width $39 \pm 8$, mode 32 (Figs. 3A, 4B). Peripheral cell number 30-32 (Table 2), 30 peripheral cells most common. Calotte small, cap-shaped, occasionally forms cephalic swelling with parapolar cells (Figs. 3C, 4D). Axial cell shape and anterior extent similar to nematogen (Fig. 4B). Verruciform cells absent. Average of 2 infusoriform embryos present in axial cell of rhombogens, with smaller individuals having only 1 and larger individuals occasionally having as many as 3 . Usually 2 , rarely 1 or 3 infusorigens present in axial cell of each parent individual.

Infusorigens (Figs. 3F, 4H; $\mathrm{n}=21$ ): Mature infusorigens small-sized; usually irregular in shape; diameters of 10-38, average of $20.1 \pm 6.4$. Composed of 5-15 (mode 7) external cells (egg line - oogonia and primary oocytes) $+3-10$ (mode 4) internal cells (sperm line - spermatogonia, primary spermatocytes and secondary spermatocytes) $+2-11$ (mode 3 ) sperm (Figs. 3F, 4H). Mean diameter of fertilised eggs $12.6 \pm 1.5$, that of sperm $1.0 \pm 0.1$.

Infusoriform embryos (Figs. 3G,H, 4I-K; $\mathrm{n}=100$ ): Full-grown embryos medium-sized, lengths average $30 \pm 3$ (excluding cilia); length: width: depth ratio $1.0: 0.8: 1.0$. Shape ovoid, rounded posteriorly (Figs. 3G, $4 \mathrm{~J}, \mathrm{~K})$. Cilia at posterior end 8 long. Refringent bodies present, solid and large; occupy $53 \%$ of embryo length when viewed laterally (Figs. $3 \mathrm{H}, 4 \mathrm{I}$ ). Cilia projecting from ventral internal cells to urn cavity (Fig. 4I). Capsule cells contain many large granules, only on side adjacent to urn (Fig. 4I). Mature infusoriform embryos consisting of 37 cells: 33 somatic +4 germinal cells. Somatic cells of several types present: external cells cover large part of anterior and lateral surfaces of embryo ( 2 enveloping cells); external cells with cilia on external surface ( 2 paired dorsal cells +1 median dorsal cell +2 dorsal caudal cells + 2 lateral caudal cells +1 ventral caudal cell +2 lateral cells +2 posteroventral lateral cells); external cells with refringent bodies ( 2 apical cells); external cells without cilia ( 1 couvercle cell +2 first ventral cells +2 second ventral cells +2 third ventral cells); internal cells with cilia ( 2 ventral internal cells); and internal cells without cilia ( 2 dorsal internal cells +2 capsule cells +4 urn cells). Each urn cell contains 1 germinal cell and 2 nuclei. All somatic nuclei appear pycnotic in mature infusoriform embryos.
Type host: Papuan cuttlefish - Sepia papuensis Hoyle (Mollusca: Cephalopoda: Sepiidae), $17.0 \mathrm{~cm}$ mantle length, $45 \mathrm{~g}$ weight (ABTC 125763).

Other hosts: None.

Type locality: Shark Bay, off Carnarvon, Western Australia, Australia $\left(25^{\circ} 00^{\prime} 43^{\prime \prime S}, 113^{\circ} 22^{\prime} 28^{\prime \prime} \mathrm{E}\right)$; collected from by-catch of a research trawl.

Additional localities: None.

Site of infection: Attached to the surface of the left and right renal appendages.

Prevalence: 7 hosts infected/7 hosts examined (100\% infection rate) (Table 1).

Specimens deposited: Three syntype slides are deposited in the Marine Invertebrates Collection, SAMA, Australia (E3741-3) and three in the NSMT, Japan (NSMT-Me 28-30).

E ty mology: The species name 'papuceum' is derived from host species, S. papuensis.

Remarks. Dicyema papuceum sp. n. has been found together with $D$. furuyi sp. n. in the left and right renal appendages of Sepia papuensis. Vermiform stages of $D$. papuceum have 30-33 peripheral cells and a total length of $1.1 \mathrm{~mm}$. This species can therefore be easily distinguished from $D$. furuyi, which is characterised by a peripheral cell count range of 22-24 and a much larger total length of $5.3 \mathrm{~mm}$.

Nine other species within Dicyema partially overlap the peripheral cell count range of 30-33, which is recorded from D. papuceum, however, none overlap with an identical range. Out of these nine species, D. papuceum can be further distinguished from four based on differences in the number of cells in infusoriform embryos: D. calamaroceum Catalano et Furuya, 2013 (39 cells), D. ganapatii Kalavati, Narasimhamurti et Suseela, 1984 (28-32 cells), D. madrasensis Kalavati, Narasimhamurti et Suseela, 1984 (28-32 cells) and D. oxycephalum Furuya, 2009 (39 cells) (Kalavati et al. 1984, Furuya 1999, Catalano and Furuya 2013).

Additionally D. koshidai Furuya et Tsuneki, 2005 and D. macrocephalum van Beneden, 1876 can be distinguished from $D$. papuceum by a much larger body size (5.0 $\mathrm{mm}$ and $7.0 \mathrm{~mm}$ respectively compared to $1.1 \mathrm{~mm}$ ) and D. sullivani McConnaughey, 1949 by much larger infusoriform embryos (lengths of 40-48 compared to 30) (van Beneden 1876, McConnaughey 1949b, Furuya and Tsuneki 2005).

The remaining two species, D. erythrum Furuya, 1999 and D. lycidoeceum Furuya, 1999 are similar to D. papuceum in body shape, calotte shape, nuclei number in urn cells of infusoriform embryos and presence of verruciform cells. However, D. erythrum can be distinguished from $D$. papuceum by smaller refringent bodies of infusoriform embryos when viewed laterally (30\% compared to $53 \%)$ and D. lycidoeceum by larger body size $(3.0 \mathrm{~mm}$ compared to $1.1 \mathrm{~mm}$ ) (Furuya 1999). This is the first dicyemid species documented and described from an Australian cuttlefish species. 

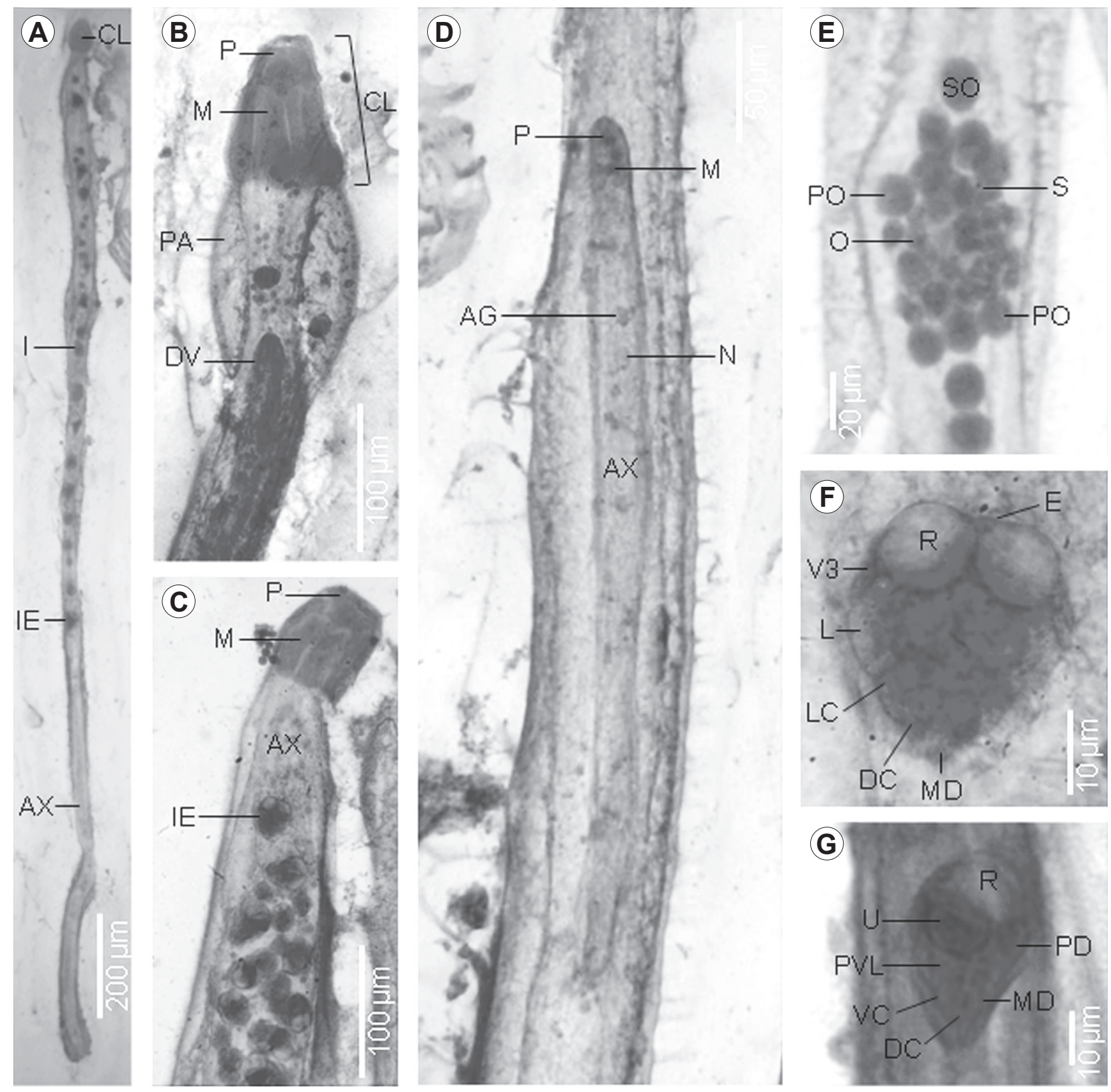

Fig. 5. Light micrographs of Dicyema furuyi sp. n. from Sepia papuensis Hoyle. A - rhombogen, entire; B - anterior region of nematogen; $\mathbf{C}$ - anterior region of rhombogen; D - vermiform embryo within axial cell; $\mathbf{E}$ - infusorigen; $\mathbf{F}, \mathbf{G}$ - infusoriform embryos within axial cell (F - optical horizontal section, $\mathrm{G}$ - optical sagittal section). Abbreviations: PVL - posteroventral lateral cells. See Fig. 1 for other abbreviations.

\section{Dicyema furuyi sp. $\mathrm{n}$.}

Figs. 5-7; Tables 1, 2

Diagnosis: Large-sized dicyemid; body length reaching $5.3 \mathrm{~mm}$. Calotte elongate. Vermiform stages with $22-$ 24 peripheral cells: 4 propolars +4 metapolars +2 parapolars $+12-14$ trunk cells; 22 peripheral cells most common. Infusoriform embryos with 37 cells; refringent bodies solid; urn cell with 1 nucleus each.

Nematogens (Figs. 5B, 6A,D, 7A,B; $\mathrm{n}=21$ ): Body slender, length $1.1-4 \mathrm{~mm}$, average length $2.1 \mathrm{~mm} \pm 841$; width 28-75, average width $48 \pm 12$, mode 56 ; trunk width mostly uniform (Fig. 6A). Peripheral cell number
22-24 (Table 2): 4 propolars +4 metapolars +2 parapolars $+10-12$ diapolars cells +2 uropolars. Calotte elongate, rounded anteriorly (Figs. 5B, 6D). Cilia on calotte approximately 7.2 long, orientated anteriorly. Propolar cells and their nuclei smaller than metapolar cells and their nuclei, respectively (Figs. 5B, 6D). Cytoplasm of propolar and metapolar cells more darkly stained by haematoxylin and eosin than cytoplasm of other peripheral cells. Verruciform cells absent. Axial cell cylindrical, rounded anteriorly; extends forward through to metapolar cells; posterior extent of axial cell through uropolar cells 
A

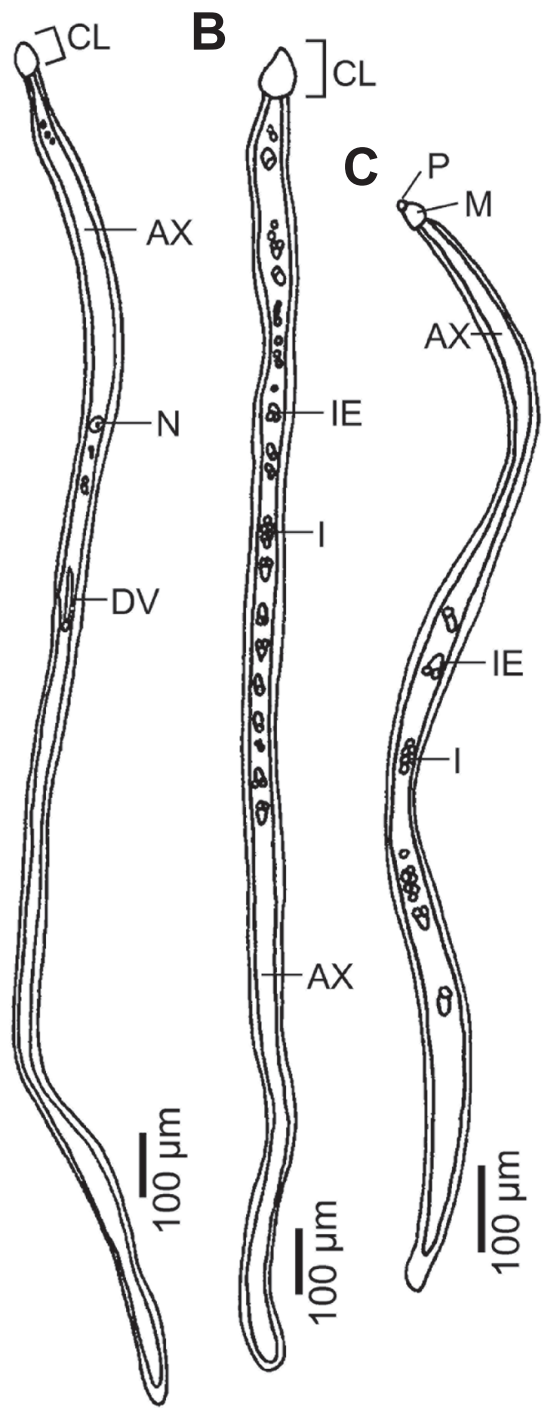

D

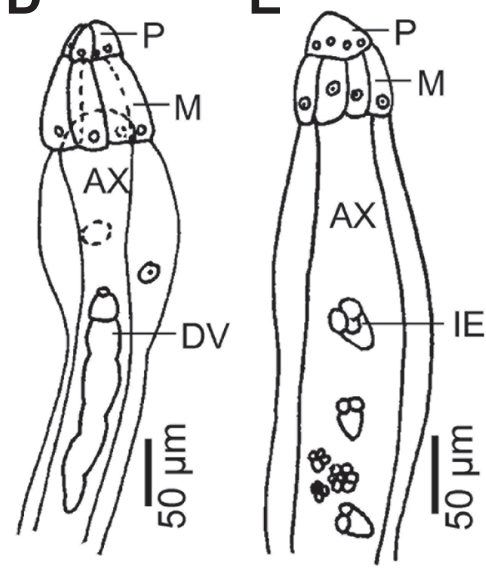

E

G

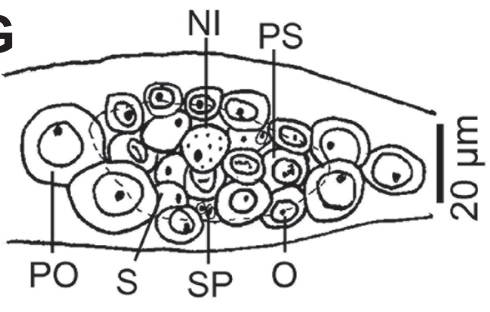

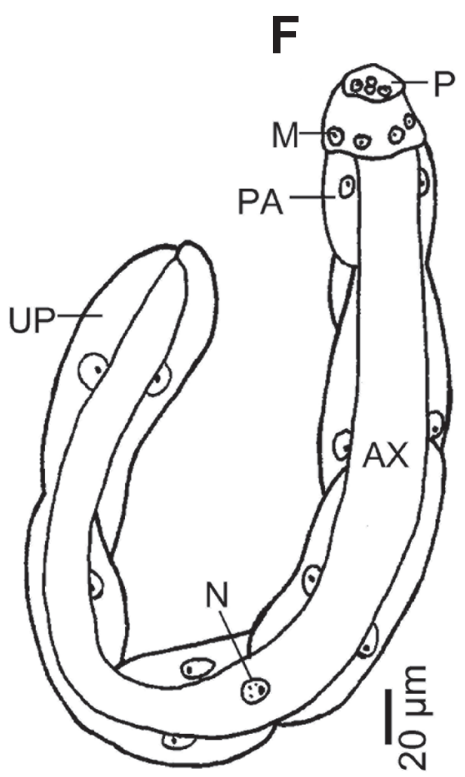
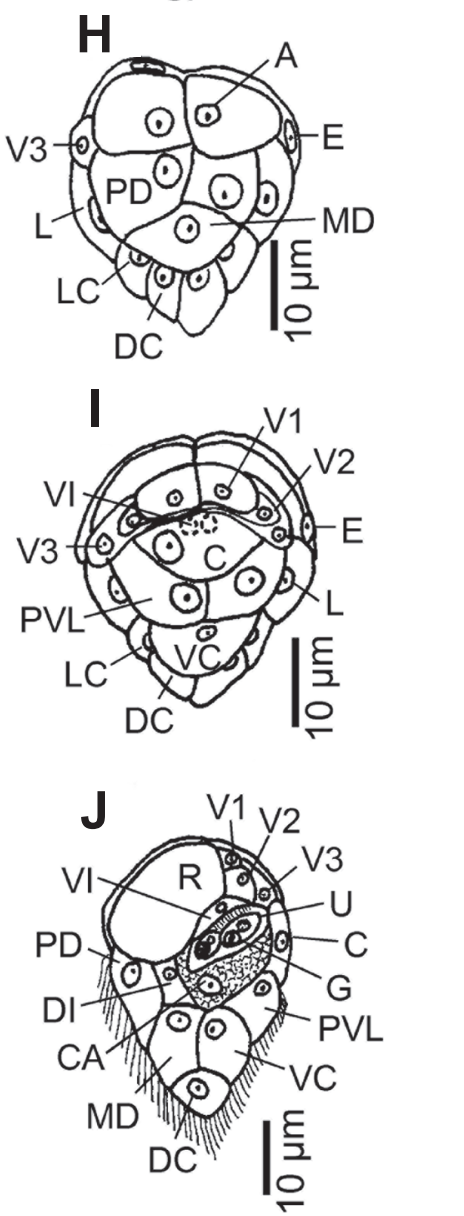

Fig. 6. Line drawings of Dicyema furuyi sp. n. from Sepia papuensis Hoyle. A - nematogen, entire; B, C - rhombogen, entire; $\mathbf{D}$ - anterior region of nematogen; $\mathbf{E}$ - anterior region of rhombogen; $\mathbf{F}$ - vermiform embryo, cilia omitted; $\mathbf{G}$ - infusorigen; H-J - infusoriform embryos within axial cell ( $\mathrm{H}$ - dorsal view, cilia omitted, I - dorsal view, cilia omitted, $\mathbf{J}$ - sagittal section). Abbreviations: DI - dorsal internal cell; PS - primary spermatocytes; PVL - posteroventral lateral cells; SP - sperm; V2 - second ventral cell; VI - ventral internal cell. See Fig. 1 for other abbreviations.

(Fig. 6A). Average of two vermiform embryos present in axial cell of nematogens, with larger individuals having as many as five vermiform embryos in axial cell. Agametes present and numerous in axial cell; average diameter $7.9 \pm 0.9$, mode 7.9 .

Three secondary nematogens observed; all with two infusorigens, 1-3 young vermiform embryos in axial cell; found in right renal appendage of two host individuals (Figs. 7A,B).

Vermiform embryos (Figs. 5D, 6F; n=21): Full-grown vermiform embryos range from 240 to 840 in length, average length $432 \pm 153$, mode 404; and range from 20 to
48 in width, average width $32 \pm 10$, mode 20. Peripheral cell number 22-24 (Table 2): 4 propolars +4 metapolars +2 parapolars $+10-12$ diapolars cells +2 uropolars; 22 peripheral cells most common. Anterior end of calotte rounded, cap-shaped in young individuals; metapolar cells larger than propolar cells (Figs. 5D, 6F). Axial cell rounded anteriorly; extends forward to middle of metapolar cells. Nucleus usually located in centre of axial cell (Fig. 6F). Anterior abortive axial cell absent. Axial cell of full-grown embryos with as many as 15 agametes.

Rhombogens (Figs. 5A,C, 6B,C,E; $\mathrm{n}=21$ ): Body slender, slightly longer than nematogens, width and shape 
otherwise similar; length $1.1-5.3 \mathrm{~mm}$, average length $2.6 \mathrm{~mm} \pm 1.2 \mathrm{~mm}$, mode $1.3 \mathrm{~mm}$, width $28-80$, average width $42 \pm 13$, mode 36 (Figs. 5A, 6B,C). Peripheral cell number 22 to 24 (Table 2), 22 peripheral cells most common. Calotte elongate, rounded anteriorly (Figs. 5C, 6E). Axial cell shape and anterior extent similar to nematogen. Verruciform cells absent. Average of 9 infusoriform embryos present in axial cell of rhombogens, with smaller individuals having as few as 3 and larger individuals having as many as 22 . Usually 1 , rarely 2 infusorigens present in axial cell of each parent individual.

Infusorigens (Figs. 5E, 6G; $\mathrm{n}=21$ ): Mature infusorigens medium-sized; usually ovoid in shape; diameters of 40-65, average of $49.0 \pm 7.1$. Composed of 9-17 (mode 12) external cells (egg line - oogonia and primary oocytes) + 6-15 (mode 11) internal cells (sperm line - spermatogonia, primary spermatocytes and secondary spermatocytes) + 3-9 (mode 3) sperm (Figs. 5E, 6G). Mean diameter of fertilised eggs $11.3 \pm 1.2$, that of sperm $1.1 \pm 0.1$.

Infusoriform embryos (Figs. 5F,G, 6H-J; n = 100): Full-grown embryos medium-sized, lengths average $33 \pm 3$ (excluding cilia); length: width: depth ratio $1.00: 0.76: 0.94$. Shape ovoid, pointed posteriorly (Figs. 5F, 6H,I). Cilia at posterior end 5.2 long. Refringent bodies present, solid and large, occupy $61 \%$ of embryo length when viewed laterally (Figs. 5G, 6J). Cilia projecting from ventral internal cells to urn cavity (Fig. 6J). Capsule cells contain many large granules (Fig. 6J). Mature infusoriform embryos consisting of 37 cells: 33 somatic +4 germinal cells. Somatic cells of several types present: external cells cover large part of anterior and lateral surfaces of embryo ( 2 enveloping cells); external cells with cilia on external surface ( 2 paired dorsal cells +1 median dorsal cell +2 dorsal caudal cells + 2 lateral caudal cells +1 ventral caudal cell +2 lateral cells +2 posteroventral lateral cells); external cells with refringent bodies ( 2 apical cells); external cells without cilia ( 1 couvercle cell +2 first ventral cells +2 second ventral cells +2 third ventral cells); internal cells with cilia ( 2 ventral internal cells); and internal cells without cilia ( 2 dorsal internal cells +2 capsule cells +4 urn cells). Each urn cell contains 1 germinal cell and 1 nucleus. All somatic nuclei appear pycnotic in mature infusoriform embryos.

Type host: Papuan cuttlefish - Sepia papuensis Hoyle (Mollusca: Cephalopoda: Sepiidae), $17 \mathrm{~cm}$ mantle length, $45 \mathrm{~g}$ weight (ABTC 125762).

Other hosts: None.

Type locality: Shark Bay, off Carnarvon, Western Australia, Australia $\left(25^{\circ} 00^{\prime} 43^{\prime \prime S}, 113^{\circ} 22^{\prime} 28^{\prime \prime} \mathrm{E}\right)$; collected from by-catch of a research trawl.

Additional localities: None.

Site of infection: Attached to the surface of the left and right renal appendages.

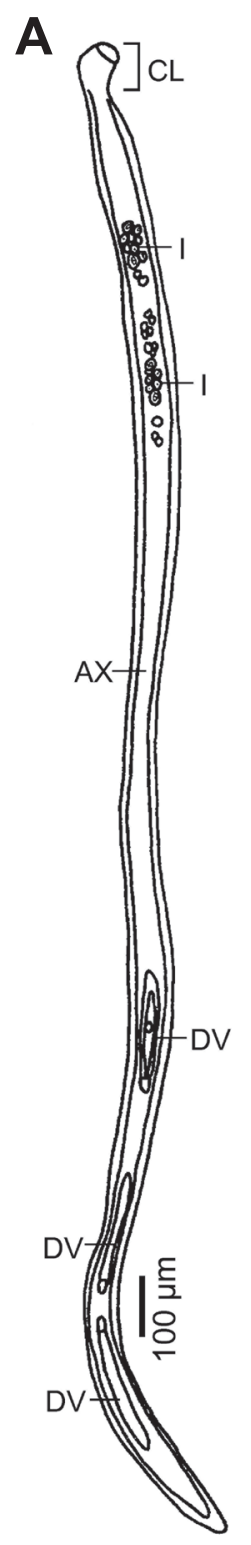

B

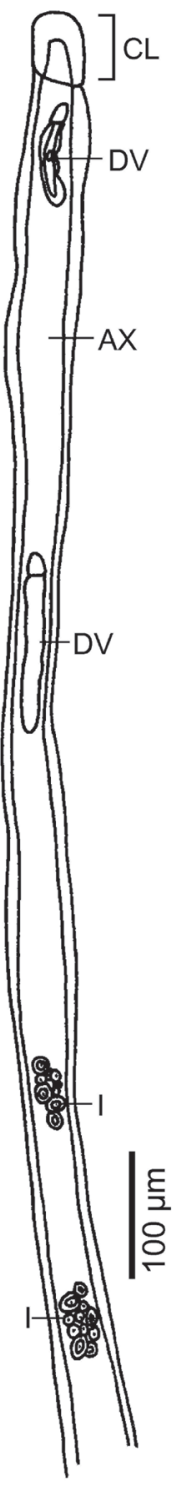

Fig. 7. Line drawings of Dicyema furuyi sp. n. secondary nematogens from Sepia papuensis Hoyle. A - secondary nematogens, entire; $\mathbf{B}$ - secondary nematogen, anterior region. See Fig. 1 for abbreviations.

Prevalence : 4 hosts infected/7 hosts examined (57\% infection rate) (Table 1$)$

S pecimens deposited: Four syntype slides are deposited in the Marine Invertebrates Collection, SAMA, Australia (E3743-6) and two in the NSMT, Japan (NSMT-Me 26-27).

E ty m o log y: The species name 'furuyi' is given in honour of Prof. Hidetaka Furuya for his invaluable contribution to the taxonomy of Dicyemida.

Remarks. Dicyema furuyi sp. n. has been found together with $D$. papuceum sp. n. in the renal appendages of Sepia papuensis. However, it can be distinguished from $D$. papuceum by the peripheral cell range (22-24 vs 30-33), calotte shape (elongate vs cap-shaped), body 
length of adults $(5.3 \mathrm{~mm}$ vs $1.1 \mathrm{~mm})$, absence of verruciform cells and presence of secondary nematogens.

Of the 63 species currently described and recognised in Dicyema (see Catalano 2012, Catalano and Furuya 2013), 29 partially overlap with a peripheral cell count range similar to that for D. furuyi (22-24). However, no species overlap with an identical peripheral cell count range. Dicyema irinoense Furuya, 2005, D. orientale Nouvel et Nakao, 1938 and D. rhadinum Furuya, 1999 are most similar to D. furuyi with overlapping peripheral cell ranges, large body sizes (over $4.0 \mathrm{~mm}$ ) and 37 cells in infusoriform embryos (Nouvel and Nakao 1938, Furuya 1999, 2005). However, D. irinoense and D. orientale can be distinguished from $D$. furuyi by the shape of the calotte (disc-shaped $v s$ elongate) and $D$. rhadinum by the number of nuclei in urn cells (2 vs 1) and length of vermiform embryos (small vs large) (Nouvel and Nakao 1938, Furuya 1999, 2005).

\section{DISCUSSION}

\section{Dicyemids in Australia}

The present study has increased the number of described dicyemid species in Australia from two to five, with new species falling within two genera, Dicyema and Dicyemennea, which comprise over $90 \%$ of the nominal dicyemid species (see Catalano 2012). Dicyemids have now been documented in Australian squid, octopus and cuttlefish host species from four families, Loliginidae, Octopodidae, Sepiadariidae and Sepiidae (Catalano and Furuya 2013; present study).

In this study, new dicyemid species were recorded from Octopus berrima and Sepia papuensis. Octopus berrima is a common, typically shallow water species endemic to temperate southern Australian waters with a distribution from the Great Australian Bight, South Australia (SA) to Twofold Bay, New South Wales (NSW), including Bass Strait and Tasmania (Stranks and Norman 1992). It has an arm span of $50 \mathrm{~cm}$ and is commonly found on sand habitats and around seagrass beds. If approached underwater, it will often bury and hide itself quickly in the sand (Norman and Reid 2000). In the study by Finn et al. (2005), the presence of dicyemid parasites was recorded in one out of one O. berrima from Gulf St. Vincent (GSV), SA and 15 out of $15 O$. berrima from Port Phillip Bay and Western Port Bay, Victoria. However, no formal descriptions were made.

All 22 host individuals collected and examined in my study from Spencer Gulf (SG) and GSV in SA waters were found to be heavily infected in both renal appendages by Dicyemennea floscephalum (100\% prevalence). Such high prevalence may be due to distribution, with Hochberg (1990) proposing a trend of low infection in cephalopods from tropical waters and high infection in cephalopods from temperate waters. However, as O. berrima frequently buries itself in the sand, this behaviour may provide the dispersive, infusoriform embryo with a high chance to find and infect new host individuals. The infusoriform embryo contains refringent bodies composed of a dense chemical that provide it with negative buoyancy (Lapan and Morowitz 1972, Lapan 1975), which is thought to allow the infusoriform embryo to remain close to the sea bottom, where it can encounter and infect a new host individual (Lapan 1975). Therefore, the high prevalence of infection by $D$. floscephalum observed in my study may be due to host behaviour rather than distributional trends.

No samples were collected from Victorian waters, so it remains to be established whether the dicyemids observed in O. berrima from Port Phillip Bay and Western Port Bay by Finn et al. (2005) are actually D. floscephalum. However, due to the highly host specific nature of dicyemid parasites (Furuya and Tsuneki 2003), it is likely that they are the same dicyemid species. This high host specificity characteristic of dicyemid parasites could be put to further use for this Octopus species. Up until 20 years ago, O. berrima was incorrectly identified and described under the name $O$. australis Hoyle (see Stranks and Norman 1992). These two species are very similar in morphology, although it is proposed that $O$. berrima is distributed in south-eastern Australia and O. australis in eastern Australia (Stranks and Norman 1992). A more accurate method to distinguish between and determine whether these two species co-occur at the boundaries of their current distributions, which may also have changed in the last 20 years ago, could be to use dicyemid parasites as biological tags. This may be advantageous, as host material is often preserved or contains individuals at different stages of maturity, which can be difficult to classify, especially with such morphologically similar (sibling) species. In particular, Voight (1994) studied the external morphology of 20 shallow water octopus species from the Atlantic and eastern tropical Pacific Oceans and, using principal components analyses, showed that measurements deemed vital to species descriptions could not identify most specimens and failed to increase understanding of octopus biology.

For $O$. berrima and $O$. australis, it would firstly need to be established that $O$. australis is infected by dicyemid parasites, then comparisons could be made between the parasite fauna of each host species collected from southeastern to eastern Australia to determine host species boundaries and whether or not mixing does occur. Such a method has been used for closely related, cryptic species on the Pacific coast of North America, O. bimaculatus Verrill and O. bimaculoides Pickford et McConnaughey being more readily identified by their dicyemid fauna than their own morphology (Pickford and McConnaughey 1949, Shulman and Hochberg 2007).

Sepia papuensis is a tropical cuttlefish species distributed along northern Australia from Western Australia to New South Wales including the Arafura Sea, Gulf of Car- 
pentaria and Coral Sea. It is found in areas of silt, sand or muddy substrates at depths between 13 and 150 metres (Norman and Reid 2000). In this study, two species of dicyemid parasites were found in the renal appendages of S. papuensis.

Dicyema papuceum was observed in all seven host individuals examined (100\% prevalence), whereas $D$. $f u$ ruyi was observed in four ( $57 \%$ prevalence). Competition between these two species for space and nutrients may be a factor resulting in the lower observed prevalence of $D$. furuyi compared to D. papuceum. However, due to the different calotte morphology of each species, which may allow them to occupy different niches along the surface of the renal appendages, direct competition may not occur (see below).

Another factor affecting prevalence may be host size. Generally $D$. furuyi was observed in larger host individuals, with mantle lengths of $12 \mathrm{~cm}$ or more (Table 1). Past studies have shown through comparative histology that the external surface of renal appendages generally varies in complexity and is correlated with host size (Furuya et al. 2004). Small-sized individuals tend to have a simple external surface, whereas larger individuals are characterised by a more complex external surface, with complexity increasing as the individual grows. Subsequently, larger individuals with increased renal appendage complexity may harbour a greater number of dicyemid species, as there is the availability of extra attachment sites compared to smaller individuals with simple surfaces (Furuya et al. 2004).

\section{Co-infection patterns}

From Australian cephalopods, typically a single species of dicyemid is present in both the left and right renal appendages of each host individual, however, two dicyemid species were detected in this study from one host, $S$. papuensis, from the same locality. In four out of seven host individuals examined, both dicyemid species were observed together, with the remaining three host individuals only infected by D. papuceum (Table 1).

Furuya (1999) states that Dicyemennea contains the largest dicyemid species, but Dicyema furuyi described in the present paper, which was found with D. papuceum in S. papuensis, represents in fact the largest dicyemid species described from an Australian cephalopod. A large body size, which is unusual for species within Dicyema, may therefore be a result of competition between these two co-occurring species. Differences in calotte shape were also observed between these two species. Dicyema furuyi has an elongate calotte, whereas D. papuceum is characterised by a small, cap-shaped calotte. Furuya et al. (2003b) examined the dicyemid fauna of cephalopod species in which more than one dicyemid species had previously been recorded. They found that when two or more species of dicyemid parasites co-occur, their calotte shapes were distinctly different, with cap-shaped calottes rarely observed unless two species of dicyemids co-exist. As the calotte is used by the dicyemid parasites to attach to the renal appendages of the host, variations in shape morphology may help to facilitate niche separation and allow one host individual to be co-infected by two or more dicyemid species, as was observed for four out of seven $S$. papuensis host individuals in this study.

\section{Secondary nematogens}

A total of three secondary nematogens were observed in the right renal appendages of two $S$. papuensis host individuals (Figs. 7A,B). This rare form, which has in the past been denied to occur at all (Gersch 1938), is characterised by containing infusorigens and infusoriform embryos together with young vermiform embryos within the axial cell, in essence having features of both adult nematogens and rhombogens (see Figs. 7A,B). McConnaughey (1951) also observed secondary nematogens, however, he stated that they are not a constant or necessary part of the life cycle, but rather occur as unusual anomalies. He proposed that they are the accidental consequence of the persistence of some axoblasts in good condition through the rhombogen period, which have been able to resume their activity and go on to once again produce vermiform larvae. Whether there is then the possibility for reversal back to a nematogen form, brought about through competition between these two modes of reproduction, and the possibility of infusorigens becoming exhausted whilst axoblasts are still being produced, is unknown. It is also unknown whether the occurrence of secondary nematogens is species specific.

Given the rare observation of this form in the present study, I agree with McConnaughey (1951) that these secondary nematogens are not a regular part of the dicyemid life cycle, but rather result by accident in the transitional period from a nematogen to rhombogen. Competition for nutrients to sustain the two modes of reproduction in the one individual must also be a factor resulting in the limited occurrence of these secondary nematogens, as it would otherwise seem favourable for the dicyemid parasite to be able to produce both vermiform and infusoriform stages within the one individual.

\section{Summary}

Three new species of dicyemid parasites were described from two cephalopod species collected from Australian waters. This increases the number of dicyemid species recorded and described from Australia to five, and presents the first record of Dicyemennea from Australian waters. The occurrence of secondary nematogens is also confirmed. Future work should continue to study and document the dicyemid parasite fauna from Australian cephalopods, as these waters are rich in cephalopod diversity, with the potential for many more dicyemid species to be discovered. 
Acknowledgments. I thank Dr Cameron Dixon and Graham Hooper at the South Australian Research and Development Institute, and Errol Sporer and Kathleen Hill at Western Australia Fisheries for organising prawn trawl trips in Spencer Gulf, Gulf St Vincent and Shark Bay, from which I was able to obtain samples. Thanks are also due to the skippers and crew who allowed me aboard vessels to analyse cephalopod material. All research was conducted with approval from the University of Adelaide Animal Ethics Committee (\#S-2010-116). Funding for this project has been provided by the Australian Society for Parasitology, Norman Wettenhall Foundation, Holsworth Wildlife Research Endowment, Sir Mark Mitchell Research Foundation,
Lirabenda Endowment Fund, Nature Foundation South Australia, Nature Conservation Society of South Australia and Australian Federation of University Women South Australia. I am grateful to Tim Benson for reading an earlier draft and I thank my supervisors Prof. Bronwyn Gillanders (University of Adelaide [UA]), Prof. Steve Donnellan (The South Australian Museum [SAMA] and UA) and Assoc. Prof. Ian Whittington (SAMA and UA) for their constructive comments and continual support. Thanks are also due to Prof. Hidetaka Furuya (Osaka University, Japan) for his help in providing me with an initial tutorial on the cell types of dicyemids and reference data sheets for measurements. SRC is funded by an Australian Postgraduate Award.

\section{REFERENCES}

VAN Beneden E. 1876: Recherches sur les Dicyemides, survivants actuels d'un embranchement des Mésozoaires. Bull. Acad. Roy. Belg. 41: 1160-1205.

Catalano S.R. 2012: A review of the families, genera and species of Dicyemida Van Beneden, 1876. Zootaxa 3479: 1-32.

Catalano S.R., Furuya H. 2013: Two new species of dicyemid (Dicyemida: Dicyemidae) from two Australian cephalopod species: Sepioteuthis australis (Mollusca: Cephalopoda: Loliginidae) and Sepioloidea lineolata (Mollusca: Cephalopoda: Sepiadariidae). J. Parasitol. 99: 203-211.

Finn J.K., Hochberg F.G., Norman M.D. 2005: Phylum Dicyemida in Australian waters: first record and distribution across diverse cephalopod hosts. Phuket Mar. Biol. Cent. Res. Bull. 66: 83-96.

Furuya H. 1999: Fourteen new species of dicyemid mesozoans from six Japanese cephalopods, with comments on host specificity. Spec. Div. 4: 257-319.

Furuya H. 2005: Three new species of Dicyema (Dicyemida: Dicyemidae) from Octopus kagoshimensis (Mollusca: Cephalopoda: Octopodidae). Spec. Div. 10: 231-247.

Furuya H. 2006: A new species of Dicyemennea Whitman, 1883 (Phylum Dicyemida) from Sepia latimanus (Mollusca: Cephalopoda: Decapodidae) off Okinawa, Japan. Syst. Parasitol. 65: 205-213.

Furuya H. 2009: Two new dicyemid from Sepia longipes (Mollusca: Cephalopoda: Decapoda). J. Parasitol. 95: 681-689.

Furuya H. 2010: A new dicyemid from Benthoctopus sibiricus (Mollusca: Cephalopoda: Octopoda). J. Parasitol. 96: 11231127.

Furuya H., Hochberg F.G. 2002: New species of Dicyemennea (Phylum: Dicyemida) in deep-water Graneledone (Mollusca: Cephalopoda: Octopoda) from the Antarctic. J. Parasitol. 88: 330-326.

Furuya H., Hochberg F.G., Tsuneki K. 2001: Developmental patterns and cell lineages of vermiform embryos in dicyemid mesozoans. Biol. Bull. 201: 405-416.

Furuya H., Hochberg F.G., Tsuneki K. 2003a: Calotte morphology in the phylum Dicyemida: niche separation and convergence. J. Zool. 259: 361-373.

Furuya H., Hochberg F.G., Tsuneki K. 2003b: Reproductive traits in dicyemids. J. Mar. Biol. 142: 693-706.

Furuya H., Hochberg F.G., Tsuneki K. 2007: Cell number and cellular composition in vermiform larvae of dicyemid mesozoans. J. Zool. 272: 284-298.

Furuya H., Ota M., Kimura R., Tsuneki K. 2004: Renal organs of cephalopods: a habitat for dicyemids and chromidinids. J. Morphol. 262: 629-643.
Furuya H., TsuneKi K. 2003: Biology of dicyemid mesozoans. Zool. Sci. 20: 519-532.

Furuya H., Tsuneki K. 2005: A new species of dicyemid mesozoan (Dicyemida: Dicyemidae) from Sepioteuthis lessoniana (Mollusca: Cephalopoda), with notes on Dicyema orientale. Spec. Div. 10: 45-62.

Gersch M. 1938: Der Entwicklungszyklus der Dicyemiden. Z. Wissensch. Zool. 151: 515-605.

HochBerG F.G. 1982: The "kidneys" of cephalopods: a unique habitat for parasites. Malacologia 23: 121-134.

Hochberg F.G. 1990: Diseases caused by protists and mesozoans. In: O. Kinne (Ed.), Diseases of Marine Animals. Vol. 3. Biologische Anstalt Helgoland, Hamburg, pp. 47-202.

Kalavati C., Narasimhamurti C.C., Suseela T. 1984: Four new species of mesozoan parasites (Mesozoa: Dicyemidae) from cephalopods of Bay of Bengal. Proc. Ind. Acad. Sci. (Anim. Sci.). 93: 639-654.

LAPan E.A. 1975: Magnesium inositol hexaphospate deposits in mesozoan dispersal larvae. Exp. Cell Res. 94: 277-282.

Lapan E.A., Morowitz H.J. 1972: The Mesozoa. Sci. Am. 227: 94-101.

McConnaughey B.H. 1949a: Dicyema sullivani, a new mesozoan from lower California. J. Parasitol. 35: 122-124.

McConnaughey B.H. 1949b: Mesozoa of the family Dicyemidae from California. Univ. Calif. Publ. Zool. 2: 1-33.

McConnaughey B.H. 1951: The life cycle of the dicyemid Mesozoa. Univ. Calif. Publ. Zool. 55: 295-336.

Norman M., Reid A.L. 2000: A Guide to Squid, Cuttlefish and Octopuses of Australasia. CSIRO Publishing, Collingswood, Victoria, $96 \mathrm{pp}$.

Norman M.D., SweEney M.J. 1997: The shallow-water octopuses (Cephalopoda: Octopodidae) of the Philippines. Invertebr. Tax. 11: 89-140.

Nouvel H. 1948: Les dicyémides II. Infusoriforme, tératologie, spécificité du parasitisme, affinités. Arch. Biol. 59: 147-224.

Nouvel H., Nakao Y. 1938: Dicyémides du Japon. Bull. Soc. Zool. France 63: 72-80.

Pickford G.E., McConnaughey B.H. 1949: The Octopus bimaculatus problem: a study in sibling species. Bull. Bingham Oceanographic Coll., Yale Univ. 12: 1-66.

Short R.B., Damian R.T. 1966: Morphology of the infusoriform larva of Dicyema aegira (Mesozoa: Dicyemidae). J. Parasitol. 52: 746-751.

Shulman D.J., Hochberg F.G. 2007: Dicyemida (Rhombozoa). In: S.F. Light and J.T. Carlton (Eds.), The Light and Smith Manual: Intertidal Invertebrates from Central California to 
Oregon. University of California Press, Berkeley, California, pp. 200-202.

Stranks T.N., Norman M.D. 1992: Review of the Octopus australis complex from Australia and New Zealand, with description of a new species (Mollusca: Cephalopoda). Mem. Mus. Vic. 53: 345-373.

Received 31 January 2013
Suzuki T.G., Ogino K., Tsuneki K., Furuya H. 2010: Phylogenetic analysis of dicyemid mesozoans (Phylum Dicyemida) from innexin amino acid sequences: dicyemids are not related to Platyhelminthes. J. Parasitol. 96: 614-625.

Voight J.R. 1994: Morphological variation in shallow-water octopuses (Mollusca: Cephalopoda). J. Zool., Lond. 232: 491-504.

Accepted 29 March 2013 